El Guiniguada • Revista de investigaciones y experiencias en Ciencias de la Educación

\title{
THE IMPACT OF USING SMARTPHONES AS STUDENT RESPONSE SYSTEMS ON PROSPECTIVE TEACHER EDUCATION TRAINING: A CASE STUDY
}

\section{EL IMPACTO DE LOS DISPOSITIVOS MÓVILES COMO SISTEMAS DE RESPUESTA PERSONAL EN LA ENSEÑANZA DE FUTUROS MAESTROS: UN ESTUDIO DE CASO}

\author{
Jesús Paz-Albo Prieto \\ Universidad Rey Juan Carlos
}

Recibido: 06/03/2015/Aceptado: 23/05/2015

\section{RESUMEN}

Las metodologías interactivas han estado tradicionalmente ausentes de las aulas de educación superior. Este artículo presenta un estudio de caso basado en una experiencia llevada a cabo en la práctica docente en los grados de educación de la Universidad Rey Juan Carlos. Este estudio exploró la eficacia del aprendizaje interactivo y la implicación del alumnado al utilizar Socrative como Sistema de Respuesta Personal (SRP), o clicker. Se realizó una encuesta para conocer las percepciones de 70 estudiantes sobre su uso. Los resultados obtenidos muestran que Socrative permite una mayor implicación y más compromiso de los estudiantes en el proceso de aprendizaje, además de favorecer la colaboración y fomentar la participación. Sin embargo, se descubrieron algunos problemas relacionados con el uso de los SRP como el abuso de los dispositivos móviles en el aula. Por último, el estudio propone varias recomendaciones sobre la utilización de los SRP en la educación superior.

Palabras clave: sistemas de respuesta personal, innovación docente, educación superior, implicación y compromiso del estudiante, aprendizaje activo. 


\begin{abstract}
Higher education classrooms have long suffered from a lack of interactivity. At Universidad Rey Juan Carlos, some instructors actively seek technologic interventions that can increase interactivity in large classes. This study explored the learning effectiveness and engagement appeal of using Socrative as a Student Response System (SRS), known as clicker, and also reports results from a formal implementation of the system in K-12 prospective teachers higher education classrooms. A questionnairebased survey was conducted to inquire into students' perceptions on their use, and data collected from 70 students was examined. As the data reveal, Socrative can much better engage students in the learning process, promoting collaboration and encouraging participation. However, some problems related to the use of SRSs were revealed such as the off-task use of the smartphones in the classroom. Recommendations were provided with respect to the use of SRSs in higher education.
\end{abstract}

Keywords: audience response systems, instructional innovation, bigher education, learner engagement, active learning.

\title{
1. INTRODUCTION
}

Existing educational policies in Spain seek to enhance and modernize the education model through the use of Innovation and Communication Technologies (ICTs) in the classroom (OECD, 2013). However, some school districts and universities around the nation have a zero-tolerance policy when it comes to cell phones out during school hours, since they assume their students are going to text, tweet or update other social media sites. But how about if using smartphones could facilitate academic learning time in the classroom, allowing our students to spend more time working on academic tasks with a high level of success?

With all the tools the Internet has brought to educators and students alike at our fingertips, it is essential to capitalize on these opportunities. In fact, the rates of growth in school internet/computer access have increased in Spain, as a high percentage of schools have improved their connectivity (ITE, 2011). Some educators are experimenting with the idea of a flipped classroom model, but interaction and feedback continue to be challenging in any K-12 classroom environment. Although research on the use of smartphones in the K-12 classroom remains limited, today's digital generation students are unique in their learning needs and they expect to use an essential part of their lives that is present in every classroom: mobile technology. 
Current research (Lee, Feldman, \& Beatty, 2012) describes the benefits of active learning approaches and using smartphones as clickers, or student response systems, is an interactive technology used to promote active learning. It enables educators to engage and assess their students by posing questions and immediately collecting and analyzing the responses of the entire class. Teachers are encouraged to increase student interaction and promote deeper learning and using tools such as Socrative (socrative.com), a Cloud-Based Student Response System, is going to be an asset we must include in the teaching-learning process. Properly applied, Student Response Systems (SRS), such as Socrative, can dramatically transform the classroom environment resulting in more learning than traditional lectures (Beatty, 2004). In fact, these technologies are attracting the interest of K-12 and higher education faculty members looking for ways to enhance courses by engaging and motivating their students to be more active learners.

At higher education settings, the use of cell phones as student response systems is becoming a part of faculty and students' lives in universities such as Carnegie Mellon University, Indiana University-Purdue, University Indianapolis, Vanderbilt University, University of Massachusetts, and Harvard University. Although there has been an interest in integrating easy-to-adopt technology into the teachinglearning process, especially by educators with a disposition towards the use of ICTs to advance the learning objectives, some teachers including university professors in countries such as Spain, are reluctant to adopt the use of ICTs in the classroom and still resort to lecturing and demonstrating. However, as envisaged in the Bologna Declaration of 1999, the European Higher Education Area (EHEA) needs to enhance the teaching quality and develop student-centered learning outcomes by empowering individual learners, adopting new approaches to teaching and learning, to provide effective support and guidance structures to all our students.

\section{WHY USE RESPONSE TOOLS?}

Research has demonstrated that when implemented successfully Student Response Systems (SRSs) could have a transformative effect on the teaching-learning process (Beatty \& Gerace, 2009; Lee, Feldman, \& Beatty, 2012). By engaging students' minds in class, Student Response System-Based Instruction fosters an active and interactive classroom environment where not only students must learn new skills and adjust to new roles but instructors as well.

We know that academic engagement is a powerful force in student academic success. While there is little research focusing on the relationship between Student Response Systems and student engagement in higher education, a number of studies have found relationships between technology use and engagement. For instance, the Dublin Institute of Technology (2011) observed that classroom response systems 
offer a tool for engaging students in the classroom. The National Survey of Student Engagement (NSSE) found the use of technology was positively related to all four of the NSSE academic challenge engagement indicators including Higher-Order Learning, Reflective and Integrative Learning, and Learning Strategies. Additionally, most educators reported that providing students with technology to facilitate learning was interwoven into the high school experience.

Although some research has been conducted on the effects of Student Response Systems (Caldwell, 2007; Bruff, 2009), little work has been done on the effect of using SRSs, such a Socrative, as part of an educational intervention on prospective bilingual teacher's education training engagement. There is clearly a need for research about student engagement in the EHEA, and the current study serves to extend previous research from the K-12 classroom (Lantz, 2010) by using an experimental design to examine the utilization of Socrative among prospective bilingual K-12 teachers from the Universidad Rey Juan Carlos and determine the impact on student motivation and engagement so educators could benefit from this research as well. Specifically, the purpose of this study was to identify students' learning perceptions regarding the use of SRSs in the higher education classroom.

\section{DATA AND METHOdOLOGY}

The population of interest for this study was one hundred and seventy prospective teachers, studying for a Degree in Early Childhood and Primary Education, from Universidad Rey Juan Carlos taking two one-semester classes where the cloud-based student response system Socrative was adopted in the 2013 academic year. None of the students had previous experience using any SRS before participating in this study.

During the first week of the semester, the instructor introduced the Socrative Student Clicker app (Figure 1) so students could turn their tablets, smartphones or laptops into clickers. The rest of the semester the instructor integrated the use of Socrative for educationally relevant activities to evaluate the students' comprehension through real time formative assessments (multiple choice, true/false and short answer questions) and gather thoughtful student data (quizzes and exit tickets) in order to maximize active learning.

In these two courses, Socrative was used as a tool to obtain student responses during lectures, to monitor student learning, to provide valuable feedback, and to improve the teaching-learning process. Because all students had access to the Internet via their smartphones, tablets or laptops, the teacher was able to gauge the whole class' level of understanding and see results in real time (Figure 2). 


\section{Jesús Paz-Albo Prieto}

The impact of using smartphones as student response systems on prospective teacher education training: a case study

\section{Figure 1. What Students See}

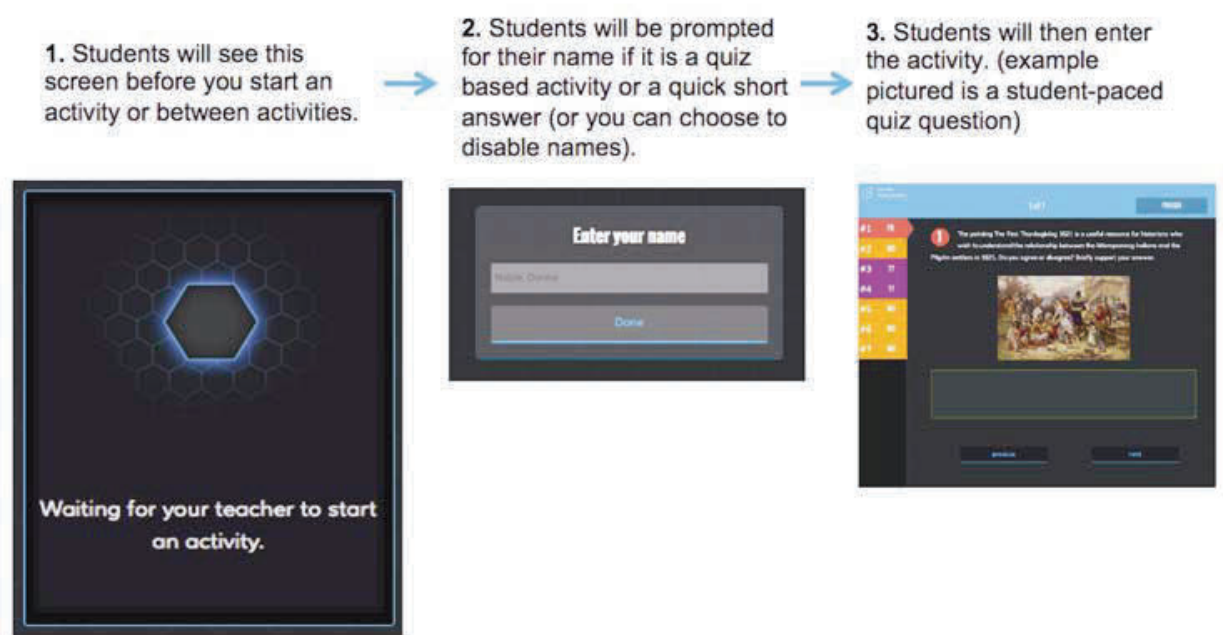

Source: Socrative User Guide, by Mastery Connect, p. 8.

Figure 2. What Teachers See

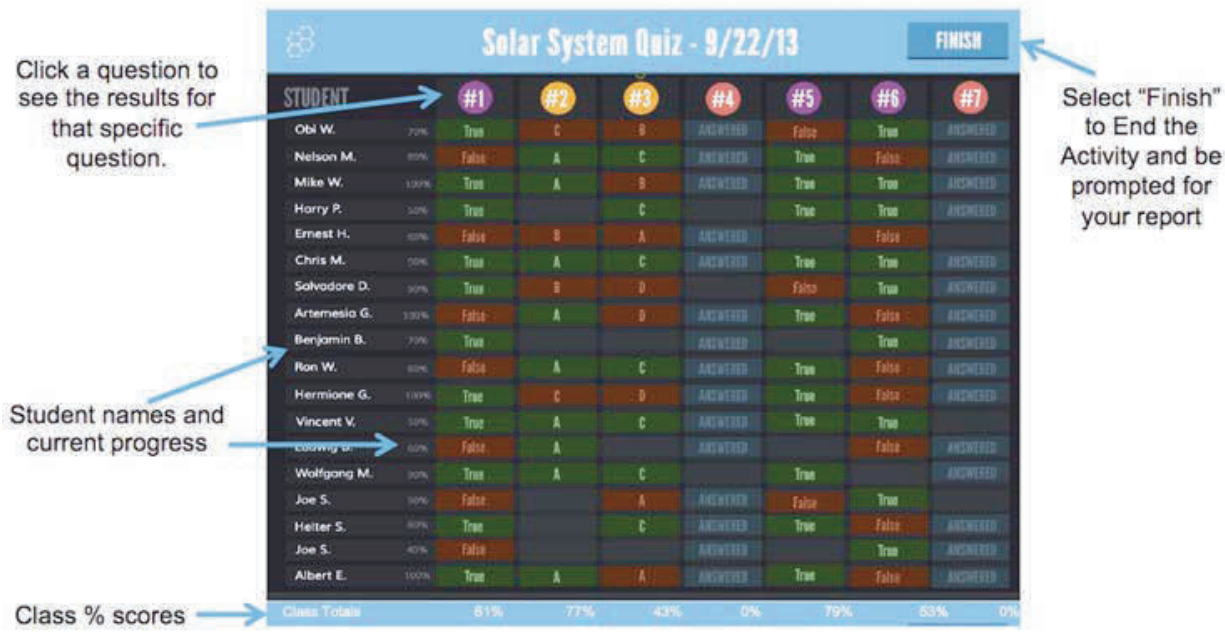

Source: Socrative User Guide, by Mastery Connect, p. 20.

Student's perceptions of their learning experience were measured by a questionnaire designed by the primary investigator. This questionnaire was reviewed by a group of teachers' educators who were content experts, revised by the primary investigator based on the teacher educators' suggestions, and then pilot tested. The final version 
of the survey instrument developed consists of seven items, divided across two sections: (1) Your Opinion Matters, and (2) In-Class Student Response System (Socrative). The first section is designed to obtain information from the students involved in the degree, including demographic information. This part of the questionnaire consisted of 3 survey items. Section 2 is intended to identify the effectiveness of SRSs, in which 11 questions were listed: eight five-point Likert scale questions and two dichotomous (Yes-No) questions were used to obtain the students' perceptions regarding their experiences with SRSs. An open question was also given in this part so that the students could write down the disadvantages of using a SRS such as Socrative from their own perspectives.

E-mail invitation messages were sent out via EncuestaFacil.com to a total of 170 prospective teachers, highlighting its purpose, while listing the reasons and benefits of the study since participation was voluntary. The validity of the returned questionnaires was checked. Of the prospective 170 teachers who could take the survey, 70 responded for an overall $41.2 \%$ participation rate. More than eighty five percent of those who responded were female and $14.29 \%$ were male. The age of our participants ranged from 18 to 45 years or older, although over $80 \%$ were between 18 and 21 years old. Final sample sizes were 44 students in the Degree in PrePrimary Education and 26 in the Degree in Primary Education. Table 1 presents the demographic data of the study's participants.

\section{Table 1. Participants}

\begin{tabular}{|l|l|l|l|l|l|}
\hline \multicolumn{2}{|c|}{ Program Type } & \multicolumn{2}{c|}{ Sex } & \multicolumn{2}{c|}{ Age } \\
\hline Pre-Primary & & Male & $20(14.29 \%)$ & $18 \mathrm{y}$ & $12(17.14 \%)$ \\
Education (Year 1) & $16(22.85 \%)$ & Female & $50(85.71 \%)$ & $19 \mathrm{y}$ & $20(28.57 \%)$ \\
Pre-Primary & & & $20 \mathrm{y}$ & $14(20.00 \%)$ \\
Education (Year 2) & $28(40.00 \%)$ & & & $21 \mathrm{y}$ & $10(14.29 \%)$ \\
\cline { 1 - 2 } Primary Education & & & & $22-24 \mathrm{y}$ & $5(7.14 \%)$ \\
(Year 1-2) & $26(37.15 \%)$ & & & $25-34 \mathrm{y}$ & $7(10.00 \%)$ \\
& & & & $45 \mathrm{y}$ & $2(2.86 \%)$ \\
\hline Total & $70(100 \%)$ & Total & $70(100 \%)$ & Total & $70(100 \%)$ \\
\hline
\end{tabular}

\section{RESUltS AND DISCUSSION}

This study used a qualitative design to obtain the students' perceptions regarding their experiences with the use of Socrative, as an educational intervention experience in education curricula at higher education settings. We collected data on 70 students (Table 1). Responses to the survey were described using means and SDs, and data was obtained from students' responses to statements provided in the survey using a 
five-point Likert scale (Table 2). Responses to the first dichotomous question showed that $95.71 \%$ of the students indicated that the use of Student Response Systems such as Socrative was helpful for their learning. The general trend is that SRSs provide more help in the classroom and students showed significantly more positive attitudes towards learning. The survey on the students' perceptions towards the use of SRSs in the classroom showed that more than $84 \%$ of the students were satisfied.

Eight Likert-type questions were formulated to assess students' experiences using Socrative. The scale ranged from 1 to 5, with 1 representing "strongly agree"; 2, "agree"; 3, "neutral"; 4, "disagree"; and 5 "strongly disagree." Findings indicated that students agreed significantly more with most statements. Table 2 describes the findings provided by the survey.

Table 2. Survey Data

\begin{tabular}{|c|c|c|}
\hline Survey Statement & Mean $^{\mathrm{a}}$ & $\mathbf{S D}^{\mathbf{b}}$ \\
\hline Using Socrative improved my engagement during lectures. & 1.729 & 0.760 \\
\hline Socrative made lectures more interactive. & 1.643 & 0.743 \\
\hline $\begin{array}{l}\text { Socrative was useful because promoted collaboration among } \\
\text { students during class. }\end{array}$ & 1.757 & 0.908 \\
\hline Using Socrative helped my understanding of course material. & 1.929 & 0.729 \\
\hline The Socrative Quizzes highlighted gaps in my knowledge. & 1.843 & 0.773 \\
\hline $\begin{array}{l}\text { The Socrative Exit Tickets helped me reflect on course content } \\
\text { during class. }\end{array}$ & 1.643 & 0.781 \\
\hline $\begin{array}{l}\text { Using Socrative encouraged participation from each and every } \\
\text { student in the class. }\end{array}$ & 1.786 & 0.915 \\
\hline I would recommend the use of Socrative for other college courses. & 1.529 & 0.775 \\
\hline
\end{tabular}

Students' perception towards the educational experience showed a similar trend for all the questions. One of the major findings was the participants' belief that using SRSs significantly enhanced their classroom experience. In fact, more than $87 \%$ of the students felt that using Socrative improved their engagement during class because it promoted collaboration among students (84.28\%) and helped their understanding of course material (80\%). The use of Socrative in class is perceived, by most students, as a tool that not only makes lectures more interactive ( $90 \%)$ but also helps them personally to reflect on course content $(87.14 \%)$. These results suggest that student engagement was high and, perhaps, this resulted in a more positive student perception of the novel experience of using a smartphone for educational purposes; and that engagement likely enhanced student involvement in the more-rigorous and relevant aspects of the lectures. 
While the great majority of participants experienced benefits of using SRSs in positive ways, 17 percent of the K-12 prospective teachers also realized that there are some disadvantages of using this online technology in the higher education classroom when answering the other dichotomous question. Participants were additionally invited to express their opinions on the use of a SRS such as Socrative in their own words. Although their views were strongly positive, they envisioned the following main limitations: off-task use of the smartphones, potential to be distracting, technical and network connectivity issues, and the university cellphone policy.

It is important that educators are aware of these types of limitations. More important, instructors should design uses for electronics that amplify the benefits of using SRSs, rather than those that highlight its limitations. The findings of this study support other research, which confirms that electronics are great for learning and the use of SRS results in better overall motivation and student engagement in class.

Although these findings describe the value of implementing the use of SRSs into education curricula, instructors must consider that simply using SRSs for the higher education classroom does not ensure its effective use. High-quality teaching is vital for student success, and SRSs can be effectively implemented within education curricula if resources are allocated for faculty development. The Socrative activities used in this study were created by the primary investigator acting as the instructor for the students participating in the study. As a result, a personal bias may have existed, and if it did exist, it may have influenced the findings of this study. Furthermore, future studies should use larger samples sizes, and the population should include undergraduate and postgraduate education programs.

\section{ConClusions}

Numerous publications that describe the use of Student Response Systems exist in the education literature. However, few studies have addressed the outcomes and students' perceptions of this educational technology in the higher education arena. Although education faculty should continue to assess students' perceptions of SRSs, as well as other innovative practices, more quantitative research is needed to investigate and evaluate learning outcomes related to the implementation of SRSs such as Socrative.

Educators could use the findings of this study to help decide whether or not to adopt smartphones as Student Response Systems in the classrooms to better meet the needs of the digital generation and increase student achievement and student engagement in the learning process. Many educators are experimenting with the idea of a flipped classroom model and smartphones are going to be an ally in this endeavor. In fact, we can see the potential of using smartphones as SRSs to influence technology instruction for the $21^{\text {st }}$ century, empowering students with a 
The impact of using smartphones as student response systems on prospective teacher education training: a case study

great tool to access valuable information in order to enhance their class experience at any educational level. The qualitative findings of this study are consistent with literature from various academic fields regarding positive responses from students about their experience using SRSs. More importantly, these findings also support the use of SRSs as an effective tool for encouraging students to get involved in class, motivating them to learn, enhancing the curriculum, and promoting active learning.

Moreover, Socrative does not only have many potential benefits to students but to teachers as well since they can adjust the pacing by gauging and evaluating students' understanding, simplify grading class, and even share pre-made quizzes with other educators making it possible to reach those students needing more attention, personalization, motivation, and encouragement to achieve their goals successfully. In the Internet age, with resources highlighting the importance of personalization, Socrative provides the students with a more personalized and engaging learning experience.

\section{REFERENCES}

Beatty, I. D. (2004). Transforming student learning with classroom communication systems. Research Bulletin ERB0403, Educause Center for Applied Research.

Beatty, I. D., \& Gerace, W. J. (2009). Technology-enhanced formative assessment: A research-based pedagogy for teaching science with classroom response technology. Journal of Education \& Technology 18(2), 146-162. doi: 10.1007/s10956-008-9140-4

Bruff, D. (2009). Teaching with classroom response systems: Creating active learning environments. San Francisco, CA: Jossey-Bass.

Caldwell, J. E. (2007). Clickers in the large classroom: Current research and best-practice tips. Life Sciences Education, 6, 9-20. doi: 10.1187/cbe.06-12-0205

Dublin Institute of Technology. (2011). Enhancement of learning with classroom response systems (clickers): Lecturer reports and feedback 2011. Retrieved from http:// wmw.dit.ie/lttc/media/ditlttc/ clickers/Clicker_report_July_2011.pdf

ITE. (2011). Indicadores y datos de las tecnologias de la información y comunicación en la educación en Europa y España. Ministerio de Educación. Instituto de Tecnologías Educativas (ITE). Departamento de Proyectos Europeos.

Lantz, M. (2010). The use of clickers in the classroom: teaching innovation or merely an amusing novelty? Computers in Human Behavior, 26(4), 556-561. doi: 10.1016/j.chb.2010.02.014

Lee, H., Feldman, A., \& Beatty, I. D., (2012). Factors that affect science and mathematics teachers' initial implementation of Technology-Enhanced Formative Assessment using a classroom response system. Journal of Education \& Technology 21(5), 523-539. doi: 10.1007/s10956-011-9344-x

Mastery Connect. (n.d.). Socrative User Guide. Retrieved from http://wmm.socrative.com/materials/ SocrativeUserGuide.pdf

OECD. (2013). Reaping the Benefits of ICTs in Spain. Strategic Study on Communication Infrastructure and Paperless Administration. Paris: OECD Publishing.

jesus.pazalbo@urjc.es 